\title{
Pharmacognostic and Phytochemical Studies of Leaves of Psydrax horizontalis Schum. \& Thonn (Rubiaceae)
}

\author{
Onyekere Peculiar Feenna ${ }^{1, *}$, Odoh Uchenna Estella ${ }^{1}$, Peculiar-Onyekere Chioma Obianuju ${ }^{2}$, Nwafor Felix \\ Ifeanyi ${ }^{1}$, Ezugwu Christopher Obodike ${ }^{1}$
}

Onyekere Peculiar Feenna ${ }^{1, *}$, Odoh Uchenna Estella ${ }^{1}$, PeculiarOnyekere Chioma Obianuju ${ }^{2}$, Nwafor Felix Ifeanyi', Ezugwu Christopher Obodike

'Department of Pharmacognosy and Environmental Medicine, Faculty of Pharmaceutical Sciences, University of Nigeria, Nsukka, 410001, Enugu StateNIGERIA.

${ }^{2}$ Department of Pharmaceutical Microbiology and Biotechnology, Faculty of Pharmaceutical Sciences, University of Nigeria, Nsukka, 410001, Enugu StateNIGERIA.

\section{Correspondence}

ONYEKERE, Peculiar Feenna

Department of Pharmacognosy \& Environmental Medicine, Faculty of Pharmaceutical Sciences, University of Nigeria, Nsukka. 410001. Enugu StateNIGERIA.

Phone no: +2348068068346

E-mail: peculiar.onyekere@unn.edu.ng peculiar.onyekere@daad-alumni.de

History

- Submission Date: 03-1-2020;

- Review completed: 23-01-2020;

- Accepted Date: 17-02-2020.

DOI : 10.5530/pj.2020.12.82

Article Available online

http://www.phcogj.com/v12/i3

\section{Copyright}

(C) 2020 Phcogj.Com. This is an openaccess article distributed under the terms of the Creative Commons Attribution 4.0 International license.

\section{ABSTRACT}

Introduction: Psydrax horizontalis Schum. \& Thonn; is used traditionally in the treatment of malaria, fever, and management of diabetes in Nsukka, South-eastern Nigeria. Owing to its increasing ethno-medicinal relevance, proper identification and evaluation are vital to prevent adulteration. This research article presents a detailed pharmacognostic, physicochemical and phytochemical evaluation on the leaves of Psydrax horizontalis which will be used in its identification and consequent standardization. Methods: The fresh and powdered leaves were evaluated for their macroscopic and microscopic features. Physicochemical properties and phytochemical screening were carried out based on standard procedures by World Health Organization (WHO). Results: Psydrax horizontalis is a petiolate, stipulate and compound bi-pinnate leaf with reticulate venation, entire margin, chordate base and has opposite leaf arrangement. Microscopic diagnostic characters observed were paracytic stomata, unicellular covering trichomes, microsphenoidal shaped calcium oxalate crystals, lignified vessels and fibres as well as numerous starch grains. The total ash, water soluble ash, sulphated ash, acid insoluble ash compositions were $6.5,0.5,2.75$ and $0.5 \%$ respectively. The moisture content, alcohol soluble extractive and water soluble extractive values obtained were $8.8,3.8$ and $3.7 \%$ respectively. Qualitative and quantitative phytochemical screening showed flavonoids, tannins, steroids, phenols and alkaloids at 100.00 $\pm 0.035,22.00 \pm 0.036,19.50 \pm 0.024,15.00 \pm 0.032$ and $13.00 \pm 0.014 \mathrm{mg} / \mathrm{g}$ respectively as the major phytochemical constituents. Conclusion: The pharmacognostic standards of the leaves of Psydrax horizontalis were determined and serve as quality control parameters for their purity, identification and standardization.

Key words: Pharmacognostic, Phytochemical, Evaluation, Microscopic, Psydrax horizontalis.

\section{INTRODUCTION}

Medicinal plants are one of the sources of natural products for the treatment and management of debilitating diseases. The use of plant extracts and isolated pure compounds has provided the basis for the production of herbal medicines and phytopharmaceutical compounds. ${ }^{1}$ For a healthcare product to be globally accepted, it must be scientifically validated to ascertain its level of purity, potency, efficacy and safety., ${ }^{2,3}$

The World Health Organization has provided standard parameters to assess the quality, safety, and efficacy of herbal plant including physicochemical and phytochemical evaluation of crude drugs. ${ }^{4}$ Various steps are involved in setting these pharmacognostic standards for the purpose of formulating a monograph of a crude drug. The quality assessment of medicinal plants is of great importance in order to justify their acceptability in conventional system of medicine. ${ }^{5}$ Uniformity of quality is promoted by the use of standards which are numerical qualities by which the quality of herbs may be assessed.

Rubiacaeae is a large family of flowering plants of 630 genera with over 13000 species widely distributed in the tropical and warm regions of the world. The Psydrax genus, which was reinstated in 1985 from the Canthium genera, is a member of the rubiacaeae family with over 37 species of various ethno-medicinal uses. ${ }^{6,7}$ Phytopharmacological and pharmacognostic studies on some of the species of Psydrax are relatively few compared to those of other genera. There is therefore need for an exploratory study on the physicochemical and pharmacognostic properties of this genus. In this present study, we have focused our evaluation on one of the medicinally important species of Psydrax- Psydrax horizontalis Schum. \& Thonn (Figure 1). It has various tradomedical uses including the treatment of malaria, fever and management of diabetes in Nsukka, Southeastern Nigeria.

We have already scientifically validated the antidiabetic activity of the leaf of Psydrax horizontalis. ${ }^{8}$ However, no previous work has been done to evaluate the physicochemical and pharmacognostic standards of the leaves of Psydrax horizontalis. This work is aimed at evaluating in detail the pharmacognostic standards of Psydrax horizontalis hence developing standardization parameters of this plant.

The plant taxonomy of Psydrax horizontalis

$\begin{array}{ll}\text { Kingdom } & \text { Plantae } \\ \text { Division } & \text { Tracheophyta }\end{array}$




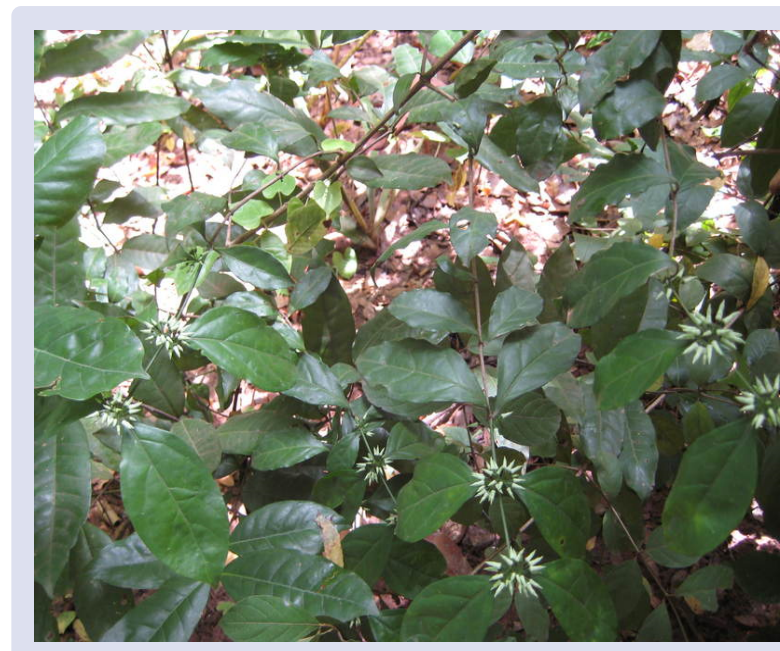

Figure 1: Photograph showing the whole plant and leaves of Psydrax horizontalis growing in Nsukka Habitat.

$\begin{array}{ll}\text { Group } & \text { Dicots } \\ \text { Class } & \text { Magnoliopsida } \\ \text { Order } & \text { Gentianales } \\ \text { Family } & \text { Rubiaceae } \\ \text { Genus } & \text { Psydrax } \\ \text { Species } & \text { horizontalis }\end{array}$

Scientific name: Psydrax horizontalis. (K.Schum. \& Thonn.) Bridson

Synonyms: Canthium caudatiflorum.Hiern, Canthium horizontale. (Schumac \& Thonn.) Hiern, Canthium anomocarpum. D.C Plectronia caudatiflora Hiern K.Schum. , Phallaria horizontalis. .(Schumac \& Thonn.)

Common Name: Akata-ike (Igbo-Nigeria).

\section{MATERIALS AND METHODS}

\section{Collection, identification and preparation of plant materials}

The leaves of Psydrax horizontalis commonly known as 'Akata-ike' (Igbo, Nigeria) were collected in Nsukka Local Government in Enugu State, Nigeria in May 2018. The plant was identified and authenticated by Mr. Felix Nwafor, taxonomist of Department of Pharmacognosy and Environmental Medicines, University of Nigeria, Nsukka. The plant name has been checked with http://www.theplantlist.org/tpl/ record/kew-170248. A sample of the plant material was deposited in our herbarium under voucher specimen number PCG/UNN/0218 for future reference. The leaves were cleaned, shade dried and used for the present study.

\section{Chemicals, reagents and solvents}

All chemicals, solvents and reagents used were of analytical grade.

\section{Equipment}

Digital microscopic eyepiece (Inco-Ambala), Metzer-Metzer Optical Instrument (Mathura), Quantitative microscopic measurements were made using eye piece, stage micrometer (Erma-Japan), and camera lucida (Prism type- Swift-Ivis). Other equipment used were thermostatic water bath (B.Bran, England), thermo-scientific furnace (USA), rotary evaporator (Stuart, UK), electronic scale (G\&G, USA).

\section{Macroscopic examination of leaves}

The fresh leaves of Psydrax horizontalis were visually examined. The organoleptic properties such as colour, odour and taste of the plant material were observed and noted The macroscopic characters of the leaves which include type of margin, venation, base, shape, size, apex, mid-rib, lamina, presence or absence of petiole were evaluated based on standard protocol. ${ }^{7-9}$

\section{Microscopic examination of leaves}

\section{Quantitative microscopy}

\section{Palisade ratio}

A piece of leaf ( $2 \mathrm{~mm}$ thick) was clarified by boiling with chloral hydrate solution for 5 minutes. It was mounted and four cells of the epidermis were traced. By focusing down to palisade layer, sufficient cells were traced off to cover the epidermal cells. The numbers of palisade cells under the four epidermal cells were counted. A range of different parts of the leaf was focused, traced and the average was calculated to get the palisade ratio of the leaf. ${ }^{10}$

\section{Stomata number and stomata index}

A piece of leaf (middle part) was clarified by boiling with chloral hydrate solution for 5 minutes. The upper and lower epidermises were peeled separately. The peeled epidermis was placed on a glass slide and mounted with glycerine water. A stage micrometer (3"x 1 "dimension and calibrated with a $1 \mathrm{~mm}$ scale, subdivided into $0.1 \mathrm{~mm}$ ) was attached to the stage of the microscope. The prepared slide was placed on the stage and epidermal cells with at least half of its area lying within the square were noted. The photomicrograph was taken with the aid of a digital microscopic eyepiece attached to a microscope. The number of stomata was counted for four different parts and the average taken represents the stomata number. ${ }^{10}$

Stomata index was calculated using the formula below:

Stomata Index $=S \times 100 / E+S$

$\mathrm{S}=$ number of stomata per unit area

$\mathrm{E}=$ number of ordinary epidermal cells (including trichomes) in the same unit area.

\section{Vein-islet number}

A piece of leaf was cleared by boiling in chloral hydrate solution. With the aid of stage micrometer, one square millimeter was drawn. The cleared leaf was mounted on a glass slide and a drop of glycerin was added then covered with cover slip. The prepared slide was placed on the stage of microscope. The average number of vein-islets from four squares was found and average number of vein-islet calculated.

\section{Vein termination number}

The average number of vein terminations present within a square was counted from four different squares to get the value for one square millimeter.

\section{Transverse section of leaf}

The leaf sample was studied microscopically by taking transverse section (T.S.) via the midrib with small portion of lamina and thin section which was double stained with hematoxylin and saffranin. The stained sections were observed under compound microscope and photos were taken with the aid of the photographic microscope. The powder sample was also mounted in different reagent and cellular diagnostic and diagnostic cell inclusions were observed. ${ }^{9}$ 
Moreover, the presence or absence of the following were observed: epidermal cells (upper and lower), epidermal hairs (type of trichomes and distribution), xylem, phloem, stomata (type and distribution) and collenchyma. Small quantity of the powdered leaves was also cleared, mounted and observed using a binocular compound microscope fitted to a digital microscopic eyepiece

\section{Chemo-microscopic examination}

Chemo-microscopic examination was carried out to determine the presence or absence of starch grain, protein, lignin, fats/oil, calcium carbonate and calcium oxalate crystals using standard techniques. ${ }^{10,11}$

\section{Determination of analytical standards}

Analytical standards and physicochemical constants of the leaf were determined to evaluate the quality and purity of the drug. ${ }^{12}$ The total ash value, water insoluble ash value, acid insoluble ash value, sulphated ash value, extractive values and moisture content.

\section{Total ash values}

A tarred nickel crucible was placed in muffle furnace for about 15 minutes at $450^{\circ} \mathrm{C}$, cooled in a desiccator for about one hour and the crucible was weighed $\left(\mathrm{W}_{1}\right) .3 .0 \mathrm{~g}$ of the powered material was placed into the nickel crucible and heated gently until all the moisture has been driven off and the plant material was completely charred $\left(\mathrm{W}_{2}\right)$. The heat was slowly increased until the carbon has vaporized and the residue was free from carbon at $650{ }^{\circ} \mathrm{C}$ and the sample turns grey (white ash). The crucible was removed with crucible tong, cooled in a desiccator, and reweighed $\left(\mathrm{W}_{3}\right)$. The percentage ash content was determined by the relationship;

$\%$ Ash $=$ Final weight of crucible $\left(W_{3}\right)$ - Initial weight of crucible $\left(W_{1}\right)$ $x 100$

Weight of sample and crucible $\left(W_{2}\right)$ - Initial weight of crucible $\left(W_{1}\right)$

\section{Water insoluble ash value}

The ash contents of the crucible obtained from Total ash were transferred into a beaker; $25 \mathrm{ml}$ of water was added into the beaker and then boiled for 5 minutes. The mixture was filtered through an ashless filter paper, and both the residue and the filter paper were dried in an oven. The ashless filter paper containing the residue was compressed into the crucible and was subjected to heat at $450^{\circ} \mathrm{C}$ until the ashless paper was eliminated. The crucible was reweighed $\left(\mathrm{W}_{3}\right)$ and the differences were noted with formula.

$\%$ Water Insoluble Ash =

Weight of sample and crucible $\left(W_{2}\right)$ - Initial weight of crucible $\left(W_{1}\right) \times 100$

Final weight of crucible $\left(W_{3)}\right.$

$\%$ Water Soluble Ash = \% Total Ash - \% Water Insoluble Ash

\section{Acid insoluble ash}

The ash obtained from total ash was transferred into a beaker containing $25 \mathrm{ml}$ of dilute hydrochloric acid and was boiled for 5 minutes. The insoluble matter was collected in a sintered crucible and an ash-less filter paper. The beaker and the crucible were washed repeatedly through the filter paper with hot water until it was free from acid. The filter paper $\mathrm{w}$ transferred into a crucible and incinerated at $500^{\circ} \mathrm{C}$ in a muffle furnace until free from carbon. The crucible with its content was cooled in a desiccator and weighed. The percentage of acid insoluble ash was calculated with reference to the air dried substance.

\section{Sulphated ash value}

A nickel crucible was ignited to a constant weight at $450{ }^{\circ} \mathrm{C}$, cooled and weighed. $3.0 \mathrm{~g}$ of the dried material was placed over the bottom of the crucible and then reweighed. The material was moistened with dilute sulphuric acid and then incinerated to $450{ }^{\circ} \mathrm{C}$ by gradually increasing the heat until it was free from carbon. The crucible was cooled in a desiccators and more dilute sulphuric acid was added. The heating was continued to about $800{ }^{\circ} \mathrm{C}$ with occasional cooling and reweighing until a constant weight was obtained. The percentage sulphated ash value was determined by difference of the two weights, thus;

$\%$ Sulphated Ash = Final weight of sample - Initial weight of sample $x 100$

$$
\text { Initial weight of sample }
$$

\section{Determination of extractive yields}

\section{Alcohol soluble extractive value}

A $5.0 \mathrm{~g}$ of the material was weighed accurately and placed in a stoppered conical flask. A $100 \mathrm{ml}$ of $90 \%$ alcohol was added and the stopper of the conical flask was replaced firmly. The flask and its contents were shaken mechanically for about 6 hours and was allowed to macerate for another 18 hours and then filtered. The filtrate was collected and evaporated to dryness, and then the residue was dried to a constant weight at $105^{\circ} \mathrm{C}$.

\section{Water soluble extractive value}

A $5.0 \mathrm{~g}$ of the material was weighed accurately and placed in a stoppered conical flask. A $100 \mathrm{ml}$ of chloroform-water was added and the stopper of the conical flask was replaced firmly. The flask and its contents were shaken mechanically for 6 hours and were allowed to macerate for another 18 hours and then filtered. The filtrate was collected and evaporated to dryness and then the residue was dried to a constant weight at $105^{\circ} \mathrm{C}$.

\section{Determination of moisture content}

A preheated, tarred porcelain crucible was weighed and its weight with lid recorded $\left(\mathrm{W}_{1}\right)$. A spatula full of the dried sample was introduced into the crucible and was reweighed, $\left(\mathrm{W}_{2}\right)$. The sample was heated in an oven at the temperature of $65{ }^{\circ} \mathrm{C}$ for 12 hours, at intervals of 6,3 , 2,1 , hours until a constant weight, followed by cooling in a desiccator before reweighing. The constant weight, $\mathrm{W}_{3}$ was noted. The percentage moisture was calculated from the relationship:

$\%$ moisture $=$ Weight of sample in crucible $\left(W_{2}\right)-$ Constant weight $\left(W_{3}\right)$ $x 100$

Weight of sample in crucible $\left(W_{2}\right)$ - Weight of crucible $\left(W_{1}\right)$

Where $W_{2}-W_{1}=$ weight of sample

$W_{2}-W_{3}=$ weight of moisture

\section{Phytochemical analysis}

\section{Qualitative phytochemical analysis of the crude extract}

Qualitative phytochemical tests to detect the presence of various secondary metabolites in both the crude extract were carried out using standard procedures. ${ }^{13,14}$

\section{Test for carbohydrates (molisch's test)}

$0.1 \mathrm{~g}$ of each sample was boiled with $2 \mathrm{ml}$ of distilled water and filtered. Few drops of $\alpha$-naphthol solution in ethanol (Molisch's reagent) were added to the filtrates. Concentrated sulphuric acid was then gently poured down the side of the test tube to form a lower layer. A purple interfacial ring indicates the presence of carbohydrates. 


\section{Test for glycosides (combined reducing sugars)}

A $5 \mathrm{ml}$ of dilute sulphuric acid was added to $0.1 \mathrm{~g}$ of the powder in a test tube, boiled for 15 minutes on a water bath, and then neutralized with $20 \%$ potassium hydroxide solution. $10 \mathrm{~mL}$ of a mixture of equal parts of Fehling solution I and II was added and heated for 5 minutes. A denser brick-red precipitate indicates the presence of glycosides.

\section{Test for alkaloids}

A $0.5 \mathrm{~g}$ of the powdered extracts was stirred in $5 \mathrm{~mL}$ of $1 \% \mathrm{HCl}$ on a steam bath for 5 minutes. The mixture was then filtered using Whatman's nol filter paper. To the filtrate, two drops of Dragendoff's reagent were added to $1 \mathrm{ml}$ of the filtrate. An orange-red colour was observed indicating the presence of alkaloids

\section{Test for saponin}

$20 \mathrm{ml}$ of distilled water was added to $2 \mathrm{~g}$ of the extract and boiled on a hot water bath for 2 minutes. The mixture was filtered while hot and allowed to cool and the filtrate was used for the following tests:

Frothing test: $5 \mathrm{ml}$ of the filtrate was diluted with $15 \mathrm{ml}$ of distilled water and shaken vigorously. A stable froth (foam) upon standing after two minutes indicates the presence of saponins.

Emulsion test: To the frothing solution was added 2 drops of olive oil and the contents shaken vigorously. The presence of an emulsion confirms that saponins are present.

\section{Test for tannins}

$1 \mathrm{~g}$ of the powdered material was boiled with $20 \mathrm{ml}$ of water, filtered and used for the following tests.

Ferric chloride test: $3 \mathrm{ml}$ of the filtrate were added a few drops of ferric chloride. A greenish-black precipitate indicates the presence of tannins.

\section{Test for flavonoids}

$10 \mathrm{ml}$ of ethyl acetate was added to $0.2 \mathrm{~g}$ of the powder and heated on a water bath for 3 minutes. The mixture was cooled, filtered and the filtrate was used for the following tests.

Ammonium hydroxide test: $4 \mathrm{ml}$ of filtrate was shaken with $1 \mathrm{ml}$ of dilute ammonia solution. The layers were allowed to separate and yellow colour in the ammoniacal layer confirms that flavonoids are present.

$1 \%$ Aluminum chloride solution test: Another $4 \mathrm{ml}$ portion of the filtrate was shaken with $1 \mathrm{ml}$ of $1 \%$ aluminum chloride solution. The layers were allowed to separate and yellow colour in the aluminum chloride layer indicates the presence of flavonoids.

\section{Test for steroids}

Five $\mathrm{mL}$ of acetic anhydride was added to $0.5 \mathrm{~g}$ of the powdered sample with $2 \mathrm{~mL} \mathrm{H}_{2} \mathrm{SO}_{4}$. A colour change from violet to blue indicates that steroids are present.

\section{Test for terpenoids (Salkowski test)}

Five $\mathrm{mL}$ of the crude extract was carefully mixed in $2 \mathrm{~mL}$ of chloroform after which concentrated $\mathrm{H}_{2} \mathrm{SO}_{4}(3 \mathrm{~mL})$ was gradually added. The formation of a reddish-brown colour at the interface indicates the presence of terpenoids.

\section{Quantitative phytochemical analysis of the crude extract}

Quantitative phytochemical tests to detect the presence of various secondary metabolites in the crude extract were carried out using standard procedures. ${ }^{13}$

\section{RESULTS}

\section{Macroscopic examination of the leaf of Psydrax horizontalis}

The macroscopic features including organoleptic characters, macromorphological and quantitative macroscopic measurements of the leaf as observed are shown in Table 1.

\section{Microscopic examination of leaf powder}

The various microscopic features of Psydrax horizontalis which are of diagnostic importance are clearly shown in Figures 2-5.

\section{Quantitative leaf microscopy}

The quantitative microscopy of the leaf of Psydrax horizontalis for palisade ratio, stomata number, stomata index, vein-islet number and veinlet termination number which are also of diagnostic importance are presented in Table 2 .

\section{Transverse section of Psydrax horizontalis leaf}

The transverse section of the leaf as seen in Figure 2 shows the presence of the upper and the lower epidermises. There was presence of closely packed palisade mesophyll cells with numerous chloroplasts (the main photosynthetic organ) and spongy mesophyll cells that are loosely fitted to leave air spaces. The midrib bears the vascular bundle which comprises the phloem (exteriorly located) and the xylem (interior located) - the main conducting organs.

\section{Chemo-microscopic examination}

The chemo-microscopic constituents including lignin, starch, calcium oxalate, etc that are present in the leaf are presented in Table 3.

\section{Table 1: Macroscopic Description of the Leaf of Psydrax horizontalis.}

\begin{tabular}{ccc}
\hline S/N & Macroscopic Features & Description \\
\hline $\mathbf{1}$ & Organoleptic Characters & Lemon green \\
$\mathbf{2}$ & Colour & $\begin{array}{c}\text { Adaxial surface: coarse } \\
\text { Abaxial surface: slightly } \\
\text { rough }\end{array}$ \\
& Texture & Non distinct \\
$\mathbf{3}$ & Odour & Bitter \\
$\mathbf{4}$ & Taste & \\
& Macromorphological Characters & Entire \\
$\mathbf{5}$ & Margin & Acuminate \\
$\mathbf{7}$ & Apex & Simple and intact \\
$\mathbf{8}$ & Composition of lamina & Lanceolate or oblong \\
& Shape of lamina & (underside) \\
$\mathbf{9}$ & Maised at the lower surface \\
$\mathbf{1 0}$ & Mid-rib & but flat on the upper surface. \\
$\mathbf{1 1}$ & Venation & Reticulate \\
$\mathbf{1 2}$ & Base & Chordate \\
$\mathbf{1 3}$ & Surface & Pubescent \\
$\mathbf{1 4}$ & Type of leaf & Compound bi-pinnate leaf \\
$\mathbf{1 5}$ & Petiole/Non-Petiole & Petiolate leaf \\
$\mathbf{1 6}$ & Leaf arrangement & Opposite \\
& Stipule/Non-Stipule & Stipulate \\
$\mathbf{1 7}$ & Quantitative Macroscopy & $10.62 \mathrm{~cm}$ \\
$\mathbf{1 8}$ & Leaf Length: & $4.64 \mathrm{~cm}$ \\
$\mathbf{1 9}$ & Leaf Width: & $2.60 \mathrm{~cm}$ \\
\hline & Length of Petiole: & \\
& & \\
& &
\end{tabular}




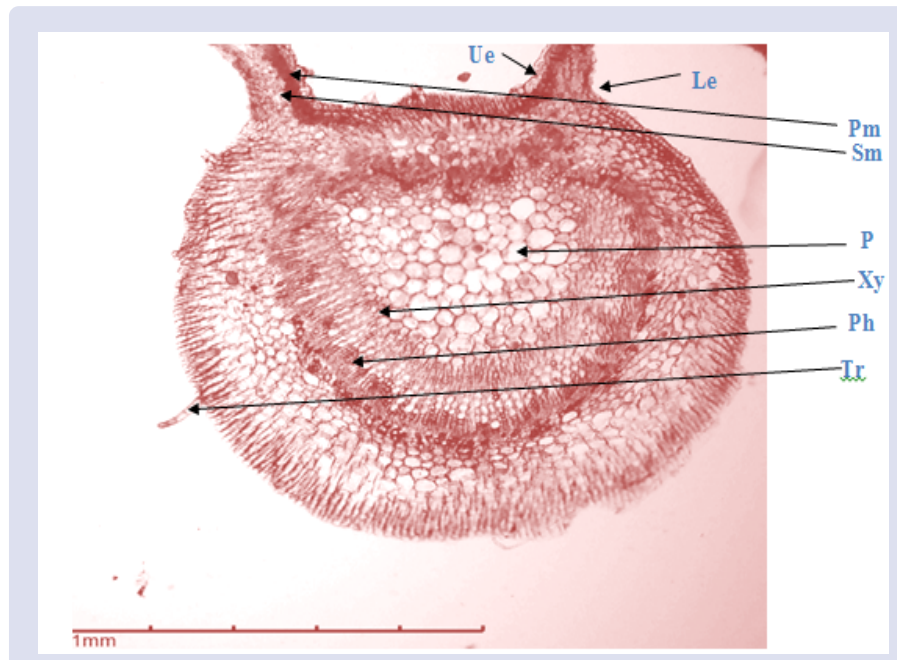

Figure 2: Photomicrograph showing the Transverse Section of the leaf lamina across the midrib 100x (Tr-Trichome, Ue- Upper epidermal layer, Le- Lower epidermal layer, Ph- Phloem, Sm-Spongy mesophyll, Xy- Xylem, Pm-Palisade mesophyll, Pt- Parenchymatous pith).

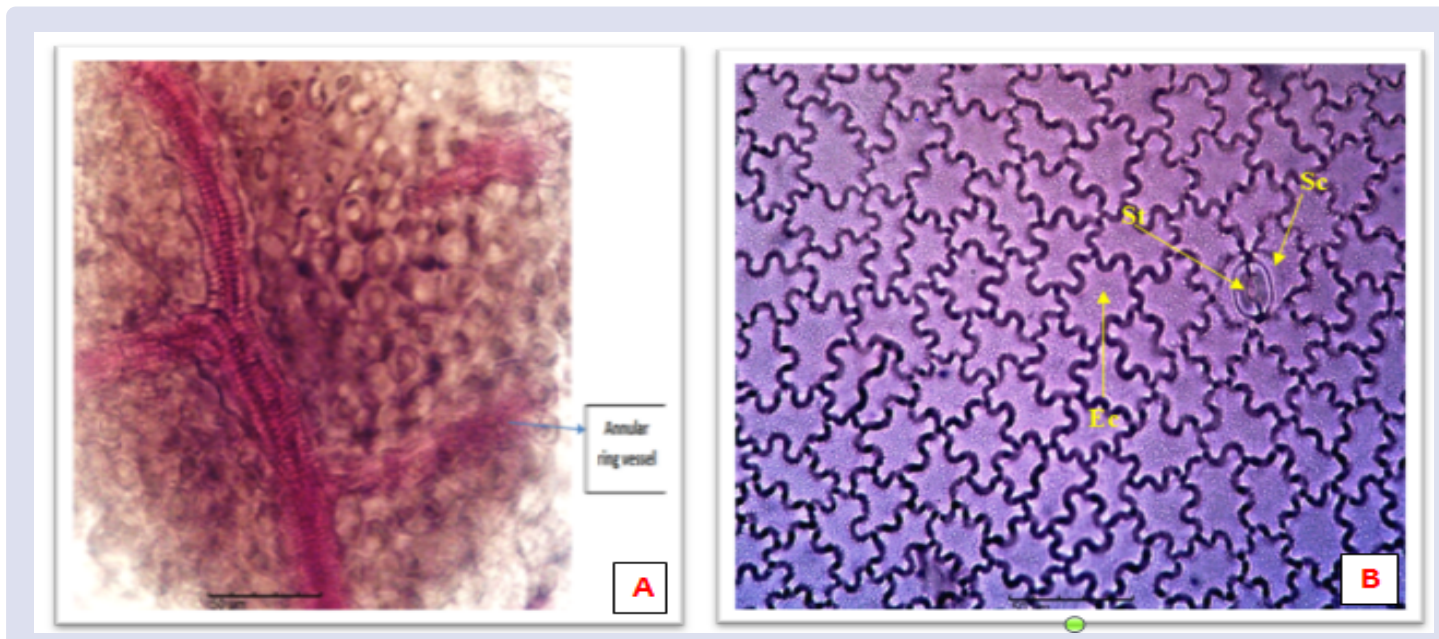

Figure 3: (A): Photomicrograph of the leaf powder of $P$. horizontalis showing pink-coloured lignified vessel tissue and palisade cells (B): Photomicrograph of leaf showing Adaxial (upper) surface of the leaf of $P$. horizontalis SC = subsidiary cell; $\mathrm{St}=$ stoma (paracytic); Ec = epidermal cell.

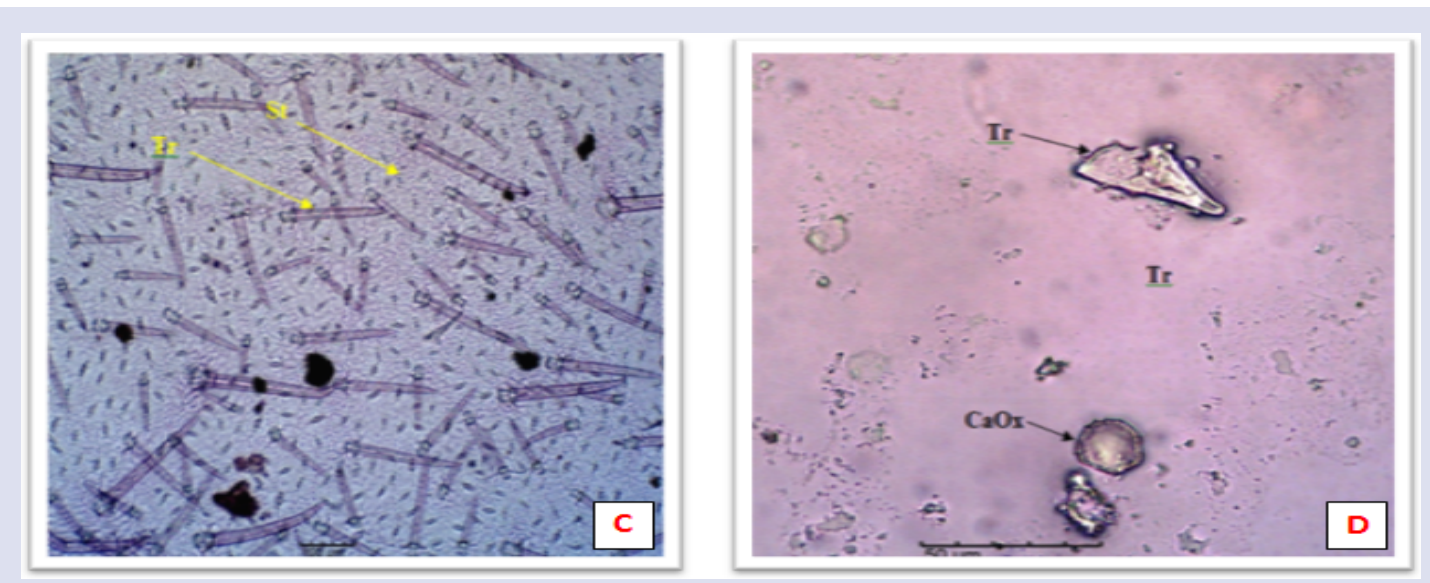

Figure 4: (C): Photomicrograph of leaf showing Abaxial (lower) surface of the leaf of $P$. horizontalis $\mathrm{Tr}=\mathrm{Trichome}$; $\mathrm{St}=$ stoma (paracytic). (D): Photomicrograph of the powder showing a fragment of covering trichome ( $T r$ ) and microsphenoidal shaped crystal of calcium oxalate (CaOx). 

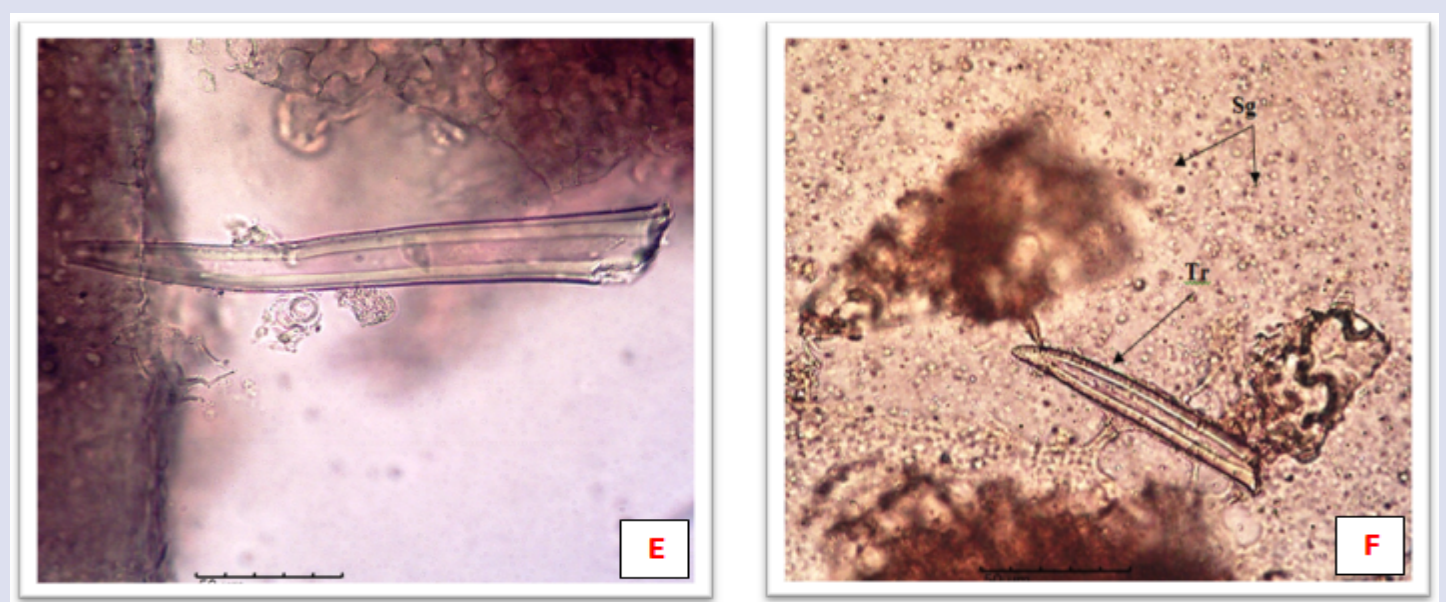

Figure 5: (E): Photomicrograph of the leaf powder showing a strand of trichome; $(F)$ : Photomicrograph of the leaf powder showing a mass of starch granules $(\mathrm{Sg})$ and a unicellular covering trichome (Tr).

Table 2: Result of Quantitative Leaf Microscopy of Psydrax horizontalis

\begin{tabular}{ccc}
\hline \multicolumn{2}{c}{ Parameter } & Values \\
\hline \multicolumn{2}{c}{ Palisade Ratio } & 3.42 \\
Vein Islet number & $3.34 \mathrm{~mm}^{-2}$ \\
Veinlet termination number & $6.12 \mathrm{~mm}^{-2}$ \\
Stomata density & Upper surface: & $5.88 \mathrm{~mm}^{-2}$ \\
& Lower surface: & $158.82 \mathrm{~mm}^{-2}$ \\
Stomata index & Upper surface & $0.8 \% ;$ \\
Stomata length & Lower surface & $16.6 \%$ \\
& Upper surface: & $20.49 \pm 0.19 \mu \mathrm{m}$ \\
Stomata width & Lower surface: & $22.76 \pm 2.20 \mu \mathrm{m}$ \\
& Upper surface: & $13.84 \pm 0.32 \mu \mathrm{m}$ \\
Stomata size & Lower surface: & $15.79 \pm 0.40 \mu \mathrm{m}$ \\
Trichome density & Upper surface: & $283.36 \pm 4.50 \mu \mathrm{m}^{2}$ \\
Trichome size & Lower surface: & $361.24 \pm 44.69 \mu \mathrm{m}^{2}$ \\
\hline
\end{tabular}

Values shown are Mean \pm SEM, $\mathrm{n}=4$

Table 3: Chemo-microscopic Characteristics of the Leaf of Psydrax horizontalis.

\begin{tabular}{|c|c|c|c|}
\hline Constituents & Reagents & Observations & Inference \\
\hline Cellulose & $\begin{array}{c}\mathrm{N} / 50 \text { iodine }+ \text { nearly dry }+80 \% \\
\mathrm{H}_{2} \mathrm{SO}_{4}\end{array}$ & Blue-black coloration & ++ \\
\hline Tannins & $\begin{array}{l}70 \% \text { methanol }+ \text { dil. } \mathrm{FeCl}_{3}+\text { more } \\
\text { dil. } \mathrm{FeCl}_{3}\end{array}$ & $\begin{array}{c}\text { Dark green color changed to olive } \\
\text { green }\end{array}$ & +++ \\
\hline Calcium carbonate & Acetic acid $+50 \% \mathrm{H}_{2} \mathrm{SO}_{4}$ & $\begin{array}{c}\text { Effervescence } \\
\text { Needle-like crystals seen }\end{array}$ & +++ \\
\hline Fats and fatty oils & Sudan iv + & Few brick red substances & ++ \\
\hline Proteins & $\begin{array}{l}\text { Few drops of ninhydrin + gentle } \\
\text { warming for } 5 \text { mins }\end{array}$ & Few yellow substances & + \\
\hline Lignins & $\begin{array}{c}\text { Few drops of phloroglucinol }+ \text { stand } \\
2-3 \text { mins }+ \text { drop conc. } \mathrm{HCl}\end{array}$ & Pink colour observed & +++ \\
\hline Starches & Few drops of N/50 iodine & Blue-black coloration & +++ \\
\hline Calcium oxalate & $\begin{array}{l}\text { Clear in chloral hydrate in glycerine } \\
+8 \% \mathrm{H}_{2} \mathrm{SO}_{4}\end{array}$ & $\begin{array}{l}\text { Shiny crystals of prisms, circular } \\
\text { and irregular shape seen }\end{array}$ & ++ \\
\hline
\end{tabular}

Key: - Absent; + Trace; ++ Present; +++ Concentrated

\section{Analytical standards of the leaf}

The analytical standards of Psydrax horizontalis leaves (total ash, water soluble ash, sulphated ash, acid insoluble ash, alcohol soluble extractive value, water soluble extractive value and moisture content) all expressed in percentage are presented in Table 4.

\section{Phytochemical analysis}

The secondary metabolites present and their various concentrations in the crude extract of Psydrax horizontalis are presented in Tables 5 \& 6 respectively. 


\section{Table 4: Results of Analytical Standards.}

\begin{tabular}{cc}
\hline Parameters & $\%$ Composition \\
\hline Total ash & $6.5 \pm 0.00$ \\
Water soluble ash & $0.5 \pm 0.00$ \\
Sulphated ash & $2.75 \pm 0.14$ \\
Acid insoluble ash & $0.5 \pm 0.00$ \\
Alcohol soluble extractive value & $3.8 \pm 0.02$ \\
Water soluble extractive value & $3.7 \pm 0.02$ \\
Moisture content & $8.8 \pm 0.02$ \\
\hline
\end{tabular}

Values of percentage composition shown are Mean \pm SEM, $n=3$

\section{Table 5: Results of Qualitative Phytochemical Analysis}

\begin{tabular}{ccc}
\hline S/N & Phytochemical Constituents & Inference \\
\hline 1. & Carbohydrates & +++ \\
2. & Reducing sugars & ++ \\
3. & Alkaloids & +++ \\
4. & Glycosides & ++ \\
5. & Saponins & ++ \\
6. & Tannins & +++ \\
7. & Flavonoids & +++ \\
8. & Steroids & ++ \\
9. & Terpenoids & +++ \\
\hline
\end{tabular}

Key: $(-)=$ Absent; $(+)=$ Present in trace amounts; $(++)=$ Moderately present; $(+++)=$ Abundantly present.

\section{Table 6: Results of Quantitative Phytochemical Analysis}

\begin{tabular}{ccc}
\hline S/N & Phytochemical & Amount $(\mathrm{mg} / \mathrm{g})$ \\
\hline 1. & Alkaloids & $13.00 \pm 0.014$ \\
2. & Glycosides & $5.30 \pm 0.045$ \\
3. & Tannins & $22.00 \pm 0.036$ \\
4. & Saponins & $4.00 \pm 0.024$ \\
5. & Flavonoids & $100.00 \pm 0.035$ \\
6. & Terpenoids & $26.00 \pm 0.026$ \\
7. & Steroids & $19.50 \pm 0.024$ \\
8. & Phenol & $15.00 \pm 0.032$ \\
\hline
\end{tabular}

Values are expressed as mean $\pm \mathrm{SEM} ; \mathrm{n}=3$

\section{DISCUSSION}

The macroscopic examination of the leaf of Psydrax horizontalis (Table 1) revealed that it is a petiolate, stipulate and compound bi-pinnate leaf with reticulate venation, entire margin, chordate base and pubescent leaf surface.

The examination of the organoleptic characters of the fresh leaves of Psydrax horizontalis revealed that the leaf is green in colour, has a smooth adaxial surface, slightly rough abaxial surface, sharp bitter taste and a non-distinct odour.

It is vital to note that macroscopic evaluation of plants is judged subjectively and substituents or adulterants may close resemble the genuine material. Hence, it is necessary to validate and authenticate the macroscopic findings by microscopic and physico-chemical analyses. ${ }^{15}$

Microscopic evaluation of crude drugs is essential for the identification of grounded or powdered materials. ${ }^{16}$ It is also one of the important pharmacognostic parameters in compilation of modern monographs

The microscopic analysis revealed several anatomical features that are peculiar and useful for diagnostic purposes. The quantitative microscopy of Psydras horizontalis leaf showed presence of numerous stomata on the lower epidermis with small number of scattered stomata cells at the upper surface. This confirms the plant as a terrestrial plant as it is one of the many adaptations of the leaf structure that help to minimize water loss from the interior. This characteristic feature was used in the determination of stomata density, stomata number, stomata index, vein-islet number, veinlet termination number and palisade ratio. Their values are all shown in Table 2.

Transverse section (TS) of the leaf shows a cup-shaped nature of the leaf. The portion of the lamina across the midrib shows both epidermises which are uniserriate trichomes. There was presence of closely packed palisade mesophyll cells with numerous chloroplasts and spongy mesophyll cells that are loosely fitted to leave air spaces. The mid rib bears the vascular bundle which comprises the phloem (exteriorly located) and the xylem (interiorly located). Some mass of parenchymatous cells formed the pith at the centre with a visible trichome (Figure 2).

The leaf is amphistomatic i.e. stomata occurred on both the upper and lower surfaces but more abundantly on the lower surface. The epidermal cells are irregularly shaped with wavy anticlinal cell walls on both the upper and lower surfaces (Figure 3). The adaxial (upper) surface of the leaf shows the presence of a paracytic stoma (Figure 3). At the abaxial (lower) surface there were numerous unicellular, non-glandular trichomes and with more stoma cells compared to the upper surface (Figure 4). The leaf powder was observed to have numerous starch granules in spongy mesophylls that are oval, which are of diagnostic importance in microscopic examination (Figure 5).

Chemo-microscopic tests carried out revealed the presence of calcium oxalate, cellulose, tannins, few proteins, fats and fatty oils, calcium carbonate, starch grains scattered all over and network of pink coloured lignins found in the vessels, fibres and epidermal cells (Table 3).

Ash values are important quantitative standards for the evaluation of the quality, identity and purity of crude drugs expecially in their powedered form. ${ }^{17-19}$ The ash values were determined by four different methods - total ash, acid insoluble ash, water soluble ash and sulphated ash and their obtained respective values were clearly stated (Table 4). The total ash obtained was $6.5 \%$ and this measures the total amount of ash remaining after ignition. This includes both 'physiological ash' which is derived from the plant tissue itself, and 'non-physiological ash. $^{20}$

Acid-insoluble ash is a part of total ash and measures the amount of silica present as sand and siliceous earth. The value of total ash and acid insoluble ash depicts the difference between mineral contaminants and deviations from the natural ash. ${ }^{21}$ The acid insoluble ash obtained was as low as $0.5 \pm 0.00$. The water soluble portion of the total ash is referred to as water soluble ash. ${ }^{21}$ The water soluble ash obtained was as low as $0.5 \pm 0.00$ which implies minimal portion of total ash constituents were soluble in water. The sulphated ash value indicates the presence of nonvolatilized residual substance and was obtained as $2.75 \pm 0.14$.

The extractive values are valuable to determine suitable solvents for extraction and furthermore assist in the evaluation of definite constituents soluble in a particular solvent. ${ }^{21,22}$ The analytical standards of leaves were within pharmacopoeia standards and it could be used as a reference guide for the identification and assessment of their quality and purity. The constituents of Psydrax horizontalis leaves were soluble in both alcohol $(3.8 \pm 0.02)$ and water $(3.7 \pm 0.02)$ with the highest solubility being in alcohol. This implies that there were more alcoholsoluble constituents like phenols, alkaloids, flavonoids, steroids and resinous materials compared to water soluble constituents like acids, gum and some inorganic compounds. ${ }^{21,22}$

The moisture content value $(8.80 \pm 0.02)$ shows possible enzymatic hydrolysis and degradation of the active components on exposure to air. High moisture content is indicative of easy degradation by fungal or bacterial growth since degradation of the plant material depends on the amount of water present. ${ }^{23}$ 
The preliminary phytochemical qualitative analysis revealed the presence alkaloids, tannins, flavonoids, steroids, saponins and terpenoids in the methanol extract.

The quantitative estimation of secondary metabolites reveals the concentrations of the various chemical constituents present in the methanol extract of Psydrax horizontalis. The flavonoids had the highest concentration of all the phytochemicals present. Phytochemical analysis uncovers the secondary metabolites and bioactive compounds which are usually responsible for the pharmacological activities of a plant drug.

\section{CONCLUSION}

Pharmacognostic standardization helps to ensure proper identification, purity and quality of medicinal plant. The pharmacognostic, physicochemical and phytochemical analyses of Psydrax horizontalis have been evaluated. The pharmacognostic and phytochemical results of Psydrax horizontalis can be employed in the preparation of official monographs and standardization of the plant

\section{CONFLICTS OF INETERST}

The authors whose names are listed above certify that they have NO affiliations with or involvement in any organization or entity with any financial interest (such as honoraria; educational grants; participation in speakers' bureaus; membership, employment, consultancies, stock ownership, or other equity interest; and expert testimony or patentlicensing arrangements), or non-financial interest (such as personal or professional relationships, affiliations, knowledge or beliefs) in the subject matter or materials discussed in this manuscript.

\section{ACKNOWLDEGMENT}

We acknowledge The Tertiary Education Trust Fund (TETFUND), Nigeria, for the support fund granted during the course of the research.

\section{REFERENCES}

1. Evans WC. Trease and Evans Pharmacognosy. Saunders an Imprint of Elsevier; 2005;41-7.

2. FiazA, Qazi NS. Pharmacognostic standardization and preliminary phytochemical studies of Gaultheria trichophylla. Pharmaceutical Biology. 2015;53(12):1-8.

3. Pan SY, Zhou SF, Gao SH, Yu ZL, Zhang SF, Tang MK, et al. New perspectives on how to discover drugs from herbal medicines: CAM'S outstanding contribution to modern therapeutics. Evidence Based Complementary Alternative Medicine. 2013;627735.

4. WHO. Quality Assurance of Pharmaceuticals: A Compendium of Guidelines and Related Materials, Good Manufacturing Practices and Inspection. Geneva: WHO, 1996

5. Govindaraghavan S, Nikolaus JS. Quality assessment of medicinal herbs and their extracts: Criteria and prerequisites for consistent safety and efficacy of herbal medicines. Epilepsy \& Behavior. 2015;52:363-71.
6. Bridson DM. The reinstatement of Psydrax (Rubiaceae, subfam Cinchonoideae tribe Vanguerieae) and a revision of the African species. Kew Bulletin.1985;40(4):687-725.

7. Sasmal DS, Kumar P, Papiamitra M, Padmacharan B, Uma RL, Dash SK, et al Review on Genus Canthium: Special Reference to Canthium coromandelicum - an Unexplored Traditional Medicinal Plant of Indian Subcontinent. American Journal of Phytomedicine and Clinical Therapeutics. 2014;2(6):796-813.

8. Onyekere PF, Odoh UE, Ezugwu CO. Phytochemical Analysis and Anti-diabetic Activity of Leaf extract of Psydrax horizontalis Schum. \& thonn (Rubiaceae). Pharmacognosy Journal. 2020;12(1): 1699-1706

9. Suresh GK, Harinath NM, Sameer JN. Microscopic Evaluation of Leaves of Memecylon umbellatum Burm. Advances in Agriculture. 2014;10(4):84-9.

10. Evans WC. Trease and Evans Pharmacognosy. $14^{\text {th }}$ edition. W. B Saunders Ltd., London. 2002;32-3.

11. Sani A, Agunu A, Danmalam HU, Ibrahim H. Pharmacognostic studies of the stem bark of Detarium microcarpum. Guill and Perr.(Fabaceae). Natural Products Chemistry and Research. 2014;(004):2-8.

12. Ayurvedic Pharmacopoeia Committee. The Ayurvedic Pharmacopoeia of India, Part I, Volume IV. New Delhi, India: Government of India, Ministry of Health and Family Welfare, Department of Ayurveda, Yoga \& Naturopathy, Unani, Siddha and Homoeopathy (AYUSH). 1999.

13. Harbourne, JB. Phytochemical methods of Analysis. Jackmann and Hall, London, 1973;64-90.

14. Sofowora AE. Medicinal plants and Traditional Medicine in Africa. $3^{\text {rd }}$ edition. Spectrum Books Limited, Spectrum House, Ring Road Ibadan, Nigeria. 2008;79-81.

15. Ajaykumar RS, Rajendra DW. Pharmacognostic study and development of quality parameters of Hamelia patens jacq. Stems. Der Pharmacia Lettre. 2016;8(8):6-13.

16. Kumar D, Pravin PV, Zulfikar AB, Jeevan D, Yogesh K, Santosh B. Macroscopical and microscopical evaluation of leaves of Clerodendrum inerme Gaertn. International Journal of Biological \& Medical Research. 2011;2(1):404-8.

17. Swamy P, Mulla SK. Preliminary pharmacognostical and phytochemical evaluation of Portulaca quadrifida Linn". International Journal of PharmTech Research. 2010;2:699-702.

18. Patnia S, Saha AN. Physicochemical, phytochemical and elemental analysis of stem bark and roots of Berberis asiatica. Advances in Applied Science Research. 2012;3:3624-8.

19. Mritunjay K, Mondal P, Borah S, Mahato K. Physicochemical evaluation, preliminary phytochemical investigation, fluorescence and TLC analysis of leaves of the plant Lasia spinose (Lour) thwaites. International Journal of Pharmacy and Pharmaceutical Sciences. 2013;5:306-10.

20. Purohit AP, Kokate $C K$, Gokhale SB. Pharmacognosy $13^{\text {th }}$ Edition. Nirali Prakashan India, 2005;256-9.

21. Shwetajain SC, Khatri P, Jain A, Vaidya A. Pharmacognostic and phyto chemical investigations of the leaves of Zizyphus xylopyrus (Retz) willd. International Journal of Pharmacy and Pharmaceutical Sciences. 2011;3:122-5.

22. Kripa KG, Sangeetha $R$, Chamundeeswari D. Pharmacognostical and physicochemical evaluation of the plant Leucas aspera. Asian Journal of Pharmaceutical and Clinical Research. 2016;9:263-8.

23. Pandey MK, Singh, GN, Sharma, RK, Lata S. Standardization of yakritplihantak churna. An ayurvedic poly herbal formulation. International Journal of Pharmaceutical Sciences Research. 2012;3:171-6. 


\section{GRAPHICAL ABSTRACT}

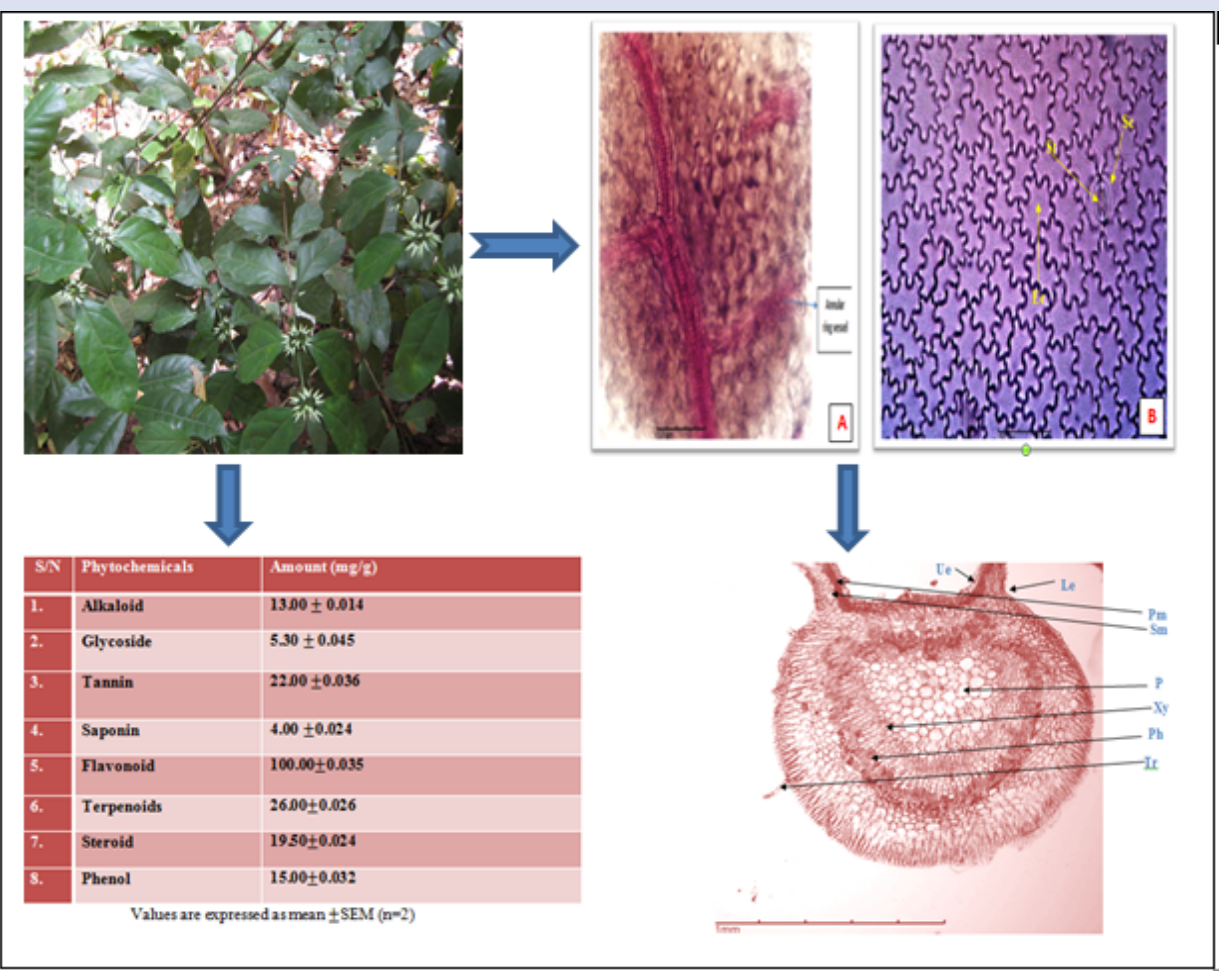

\section{ABOUT AUTHORS}

\section{ONYEKERE, Peculiar Feenna}

\section{Pharmacist, Researcher \& Lecturer}

He is a DAAD fellow and doctoral student. His research interest include natural product chemistry, phytochemistry and drug discovery/development for the treatment of chronic diseases such as diabetes and other oxidative degenerative diseases. He supervises some undergraduate pharmacy students in the Department.

Affiliation:

Department of Pharmacognosy \& Environmental Medicine, Faculty of Pharmaceutical Sciences, University of Nigeria, Nsukka. 410001. Enugu State-Nigeria.

Department of Health Sciences, Hamburg University of Applied Sciences, HAW Hamburg, Germany.

E-mail: peculiar.onyekere@unn.edu.ng, peculiar.onyekere@daad-alumni.de

Telephone: +2348068068346

\section{ODOH, Uchenna Estella}

She is a Professor of Pharmacognosy \& Environmental Medicine. Her research interests include phytochemistry, natural product chemistry, drug evaluation and quality control. She has supervised many undergraduate and postgraduate students in the Department.

Address: Department of Pharmacognosy \& Environmental Medicine, Faculty of Pharmaceutical Sciences, University of Nigeria, Nsukka. 410001. Enugu State, Nigeria.

E-mail: uchenna.odoh@unn.edu.ng

Phone No: +2348063831237

\section{PECULIAR-ONYEKERE, Chioma Obianuju}

She is a doctoral student at the Department of Pharmaceutical Microbiology \& Biotechnology, Faculty of Pharmaceutical Sciences, University of Nigeria Nsukka. Her research interest include medical microbiology, antimicrobial resistance studies using natural products, neglected tropical diseases. 
Address: Department of Pharmaceutical Microbiology \& Biotechnology, Faculty of Pharmaceutical Sciences University of Nigeria, Nsukka. 410001. Enugu State. Nigeria.

E-mail: chiomawankwo@gmail.com

Phone No:+2347064944143

\section{NWAFOR Felix Ifeanyi}

$\mathrm{He}$ is a certified taxonomist and bioprospector at the Herbarium Unit, Department of Pharmacognosy and Environmental Medicine, University of Nigeria, Nsukka. He has carried out many research works using medicinal plants at local and international levels.

Affiliation: Department of Pharmacognosy \& Environmental Medicine,

Faculty of Pharmaceutical Sciences, University of Nigeria, Nsukka. 410001. Enugu State, Nigeria.

E-mail: felix.nwafor@unn.edu.ng

Phone No: 08036062242.

\section{EZUGWU, Christopher Obodoike}

\section{He is a Professor of Pharmacognosy \& Environmental Medicine.}

His research interests include ethnobotany and phytochemistry. He is the current Head of Department of Pharmacognosy \& Envrionmental Medicine. He has supervised many undergraduate and postgraduate students.

Affiliation: Department of Pharmacognosy \& Environmental Medicine,

Faculty of Pharmaceutical Sciences, University of Nigeria, Nsukka. 410001. Enugu State, Nigeria.

E-mail: oechristo@yahoo.co.uk;

Phone No: +2348037786689

Cite this article: Onyekere PF, Odoh UE, Peculiar-Onyekere CO, Nwafor FI and Ezugwu CO. Pharmacognostic and Phytochemical Studies of Leaves Psydrax horizontalis Schum. \& Thonn (Rubiaceae). Pharmacog J. 2020;12(3):541-50. 